\title{
COMPOSITES BASED ON INORGANIC MATRICES FOR EXTREME EXPOSURE CONDITIONS
}

\author{
KOMPOZITI Z ANORGANSKO OSNOVO ZA IZPOSTAVITEV \\ EKSTREMNIM RAZMERAM
}

\author{
Amos Dufka, Tomáš Melichar \\ Brno University of Technology, Faculty of Civil Engineering, Institute of Building Materials and Components, Veveř́ 95, 60200 Brno, Czech \\ Republic \\ dufka.a@fce.vutbr.cz,melichar.t@ffe.vutbr.cz
}

Prejem rokopisa - received: 2014-08-18; sprejem za objavo - accepted for publication: 2015-01-06

doi:10.17222/mit.2014.205

\begin{abstract}
The vast majority of reinforced-concrete structures are exposed to aggressive substances from the environment during their exploitation. The consequence is the degradation of the materials and reduction in the lifetime of the structures. Therefore, it is natural to make an effort to develop and apply the materials that are maximally resistant to such conditions. Materials based on alkali-activated matrices show a high resistance against chemically aggressive environments. The article is focused on the use of the materials based on alkali-activated substances as repair materials for the structures exposed to aggressive groundwater.

Keywords: alkali-activated substances, aggressive surrounding, durability of structures

Velika večina betonskih konstrukcij je med uporabo izpostavljena agresivnim snovem iz okolja. Posledica je razpadanje materiala in skrajšanje trajnostne dobe konstrukcije. Zato je naravno, da si prizadevamo razviti in uporabiti materiale, ki so najbolj zdržljivi v danih razmerah. Materiali, ki imajo z alkalijami aktivirano osnovo, izkazujejo veliko odpornost pri izpostavitvi kemijsko agresivnemu okolju. Clanek obravnava uporabo materialov, ki temeljijo na snoveh, aktiviranih z alkalijami, kot materialih za popravilo konstrukcij, ki so izpostavljene agresivni talni vodi.

Ključne besede: $\mathrm{z}$ alkalijami aktivirane snovi, agresivno okolje, zdržljivost konstrukcij
\end{abstract}

\section{INTRODUCTION}

A lot of structures are exposed to the environments that are, due to their chemistry, quite aggressive to reinforced concrete. The material's resistance against the aggressive substances from the external environment is mainly determined by the features of its matrix. ${ }^{1}$ Compared to concrete stone, the materials with the matrices based on alkali-activated substances have a significantly higher resistance to chemical substances. The article deals with the development and, especially, the application of the repair materials based on alkali-activated materials used for the repair of the reinforced-concrete lining of an underground collector used in a chemically aggressive environment.

\section{SPECIFICATIONS OF THE COLLECTOR AND THE CONDITIONS OF ITS EXPLOITATION}

The excavation of the underground collector was done using the machine-excavation technology, while the final scraping of the excavation area was carried out with the classical, manual excavation method. The excavation area is from $13 \mathrm{~m}^{2}$ to $14 \mathrm{~m}^{2}$ (by stationing). The length of the underground part of the collector is $7.87 \mathrm{~km}$; the lining and casing of the tunnels are made of shotcrete, whose strength within this project is determined to be 20 $\mathrm{MPa}$. The lining of the tunnels is reinforced with welded mesh panels ( $\varnothing 6-100 / 100 \mathrm{~mm}$ ) and a rigid mine casing. The thickness of the shotcrete is $100 \mathrm{~mm}$. Dry shotcrete was applied.

Already one year after the construction, significant defects began to occur. These were mainly the penetration of water through the lining, new formations of solid carbonate on the surface of the lining, the formation of waste products associated with the reinforcement corrosion, etc. A typical state of the damaged lining after one year of operation is shown in Figures $\mathbf{1}$ and 2.

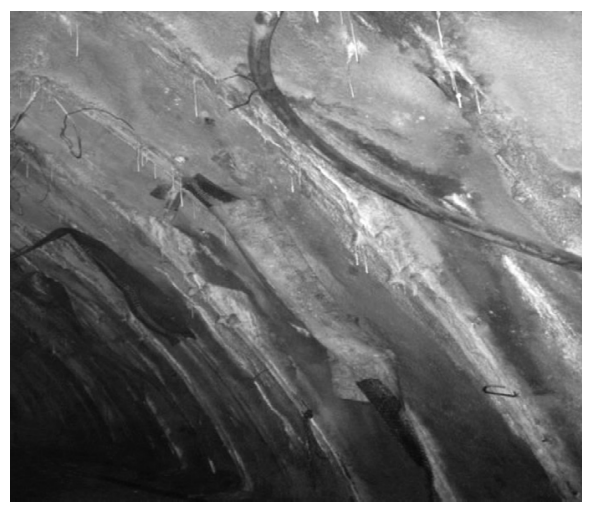

Figure 1: View of the location, in which a massive penetration of moisture occurred: new solid-carbonate formations are visible on the surface of the lining

Slika 1: Prikaz področja, kjer se je pojavila močna penetracija vlage; viden je nastanek trdnega karbonata na površini podlage 


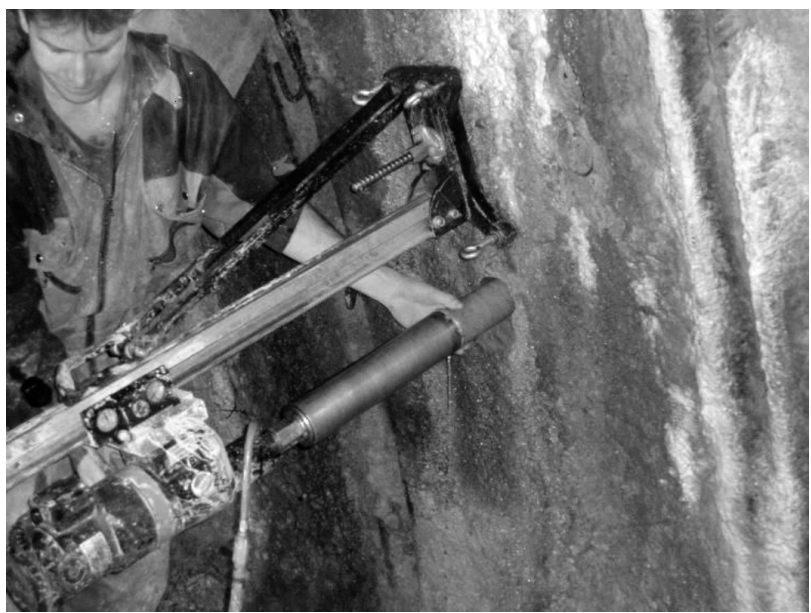

Figure 2: Collection of core bores from the lining. Significant carbonate efflorescence is visible on the surface of the wall.

Slika 2: Zbiranje jeder iz izvrtine v podlagi. Na površini stene je viden močan razcvet karbonatov.

The state of the structure continued to deteriorate very quickly and, therefore, it was necessary to take corrective measures. It was found that before the construction of the collector no hydrogeological survey was performed, or it was performed unprofessionally and insufficiently.

To properly assess the causes of the failures, a detailed construction and technical investigation was carried out in the places where the state of the concrete was being evaluated, and an analysis of the chemical composition of the groundwater in various locations of the collector was performed. The results of the chemical analysis of the groundwater are given in Table $\mathbf{1}$.

The foregoing shows that in terms of the durability of the concrete the amount of sulphate ions in the water is essential. The aggressiveness of the environment in different parts of the collector can be classified as relevant in accordance with EN 206-1 (Table 2).

Table 1: Results of the chemical analysis of groundwater Tabela 1: Kemijska analiza talnice

\begin{tabular}{|c|c|c|c|}
\hline $\begin{array}{c}\text { Chemical } \\
\text { composition }\end{array}$ & $\begin{array}{c}\text { Stationing } \\
0.57 \mathrm{~km} \mathrm{-} \\
\text { tertiary } \\
\text { sediments }\end{array}$ & $\begin{array}{l}\text { Stationing } \\
1.56 \mathrm{~km} \mathrm{-} \\
\text { quaternary } \\
\text { sediments }\end{array}$ & $\begin{array}{c}\text { Stationing } \\
2.68 \mathrm{~km}- \\
\text { tertiary } \\
\text { sediments }\end{array}$ \\
\hline Alkalinity & 7.68 & 7.50 & 7.70 \\
\hline Sulphates & $3450 \mathrm{mg} \mathrm{L}^{-1}$ & $148 \mathrm{mg} \mathrm{L}^{-1}$ & $1369 \mathrm{mg} \mathrm{L}^{-1}$ \\
\hline Chlorides & $170 \mathrm{mg} \mathrm{L}^{-1}$ & $152 \mathrm{mg} \mathrm{L}^{-1}$ & $260 \mathrm{mg} \mathrm{L}^{-1}$ \\
\hline Nitrates & $146 \mathrm{mg} \mathrm{L}^{-1}$ & $124 \mathrm{mg} \mathrm{L}^{-1}$ & $180 \mathrm{mg} \mathrm{L}^{-1}$ \\
\hline Ammonia ions & $0.17 \mathrm{mg} \mathrm{L}^{-1}$ & $0.13 \mathrm{mg} \mathrm{L}^{-1}$ & $0.08 \mathrm{mg} \mathrm{L}^{-1}$ \\
\hline $\begin{array}{l}\text { Chemical } \\
\text { composition }\end{array}$ & $\begin{array}{c}\text { Stationing } \\
4.42 \mathrm{~km} \mathrm{-} \\
\text { tertiary } \\
\text { sediments }\end{array}$ & $\begin{array}{c}\text { Stationing } \\
5.93 \mathrm{~km} \mathrm{-} \\
\text { tertiary } \\
\text { sediments }\end{array}$ & $\begin{array}{l}\text { Stationing } \\
6.67 \mathrm{~km} \mathrm{-} \\
\text { quaternary } \\
\text { sediments }\end{array}$ \\
\hline Alkalinity & 7.15 & 7.25 & 7.38 \\
\hline Sulphates & $3825 \mathrm{mg} \mathrm{L}^{-1}$ & $1740 \mathrm{mg} \mathrm{L}^{-1}$ & $193 \mathrm{mg} \mathrm{L}^{-1}$ \\
\hline Chlorides & $156 \mathrm{mg} \mathrm{L}^{-1}$ & $78 \mathrm{mg} \mathrm{L}^{-1}$ & $178 \mathrm{mg} \mathrm{L}^{-1}$ \\
\hline Nitrates & $160 \mathrm{mg} \mathrm{L}^{-1}$ & $112 \mathrm{mg} \mathrm{L}^{-1}$ & $134 \mathrm{mg} \mathrm{L}^{-1}$ \\
\hline Ammonia ions & $4.12 \mathrm{mg} \mathrm{L}^{-1}$ & $0.17 \mathrm{mg} \mathrm{L}^{-1}$ & 16. $\mathrm{mg} \mathrm{L}^{-1}$ \\
\hline
\end{tabular}

Table 2: Evaluation of groundwater aggression

Tabela 2: Ocena poškodb zaradi talne vode

\begin{tabular}{|c|c|}
\hline $\begin{array}{c}\text { Stationing } \\
0.57 \mathrm{~km}-\text { tertiary sediments }\end{array}$ & $\begin{array}{c}\text { Highly aggressive } \\
\text { environment }\end{array}$ \\
\hline $\begin{array}{c}\text { Stationing } \\
1.56 \mathrm{~km}-\text { quaternary sediments }\end{array}$ & No aggression \\
\hline $\begin{array}{c}\text { Stationing } \\
2.68 \mathrm{~km}-\text { tertiary sediments }\end{array}$ & $\begin{array}{c}\text { Moderately aggressive } \\
\text { chemical environment }\end{array}$ \\
\hline $\begin{array}{c}\text { Stationing } \\
4.42 \mathrm{~km}-\text { tertiary sediments }\end{array}$ & $\begin{array}{c}\text { Highly aggressive } \\
\text { environment }\end{array}$ \\
\hline $\begin{array}{c}\text { Stationing } \\
5.93 \mathrm{~km}-\text { tertiary sediments }\end{array}$ & $\begin{array}{c}\text { Moderately aggressive } \\
\text { chemical environment }\end{array}$ \\
\hline $\begin{array}{c}\text { Stationing } \\
6.67 \mathrm{~km}-\text { quaternary sediments }\end{array}$ & No aggression \\
\hline
\end{tabular}

On the basis of the results of the chemical analysis of the water samples it was possible to conclude that the water that passes through quaternary sediments does not cause the sulphate corrosion of the concrete. A completely different situation occurs when the water passes through tertiary sediments. These waters show moderate and, in some areas, even high sulphate aggressiveness. The results of the chemical analysis clearly demonstrated a high level of aggressiveness of the groundwater affecting the collector. Underestimating this fact or failing to carry out a hydrogeological research before the construction of a collector is, therefore, shown to be a serious deficiency.

To assess the actual state after two years of the operation of the collector, a construction and technical research was performed, aimed especially to:

- assess the state of the concrete, in terms of both physical and mechanical parameters (i.e., particularly in terms of compressive strength) and in terms of its chemical and mineralogical compositions;

- assess the state of the reinforcement and the degree of its corrosion, especially in connection to the concrete's ability to passivate the reinforcement corrosion with its natural alkalinity.

The process of the construction and technical research was carried out in accordance with the provisions of the Technical Conditions for Reinforced Concrete Structure Reinstalment ${ }^{1}$ and the relevant technical stan-

Table 3: Concrete's compressive strength depending on the aggressiveness of groundwater in different parts of the collector

Tabela 3: Trdnost betona v odvisnosti od poškodb zaradi talne vode na različnih pozicijah kolektorja

\begin{tabular}{|c|c|}
\hline $\begin{array}{c}\text { Stationing } \\
0.57 \mathrm{~km}-\text { tertiary sediments }\end{array}$ & $8 \mathrm{MPa}$ \\
\hline $\begin{array}{c}\text { Stationing } \\
1.56 \mathrm{~km}-\text { quaternary sediments }\end{array}$ & $25 \mathrm{MPa}$ \\
\hline $\begin{array}{c}\text { Stationing } \\
2.68 \mathrm{~km}-\text { tertiary sediments }\end{array}$ & $14 \mathrm{MPa}$ \\
\hline $\begin{array}{c}\text { Stationing } \\
4.42 \mathrm{~km}-\text { tertiary sediments }\end{array}$ & $10 \mathrm{MPa}$ \\
\hline $\begin{array}{c}\text { Stationing } \\
5.93 \mathrm{~km}-\text { tertiary sediments } \\
\text { Stationing } \\
6.67 \mathrm{~km}-\text { quaternary sediments }\end{array}$ & $16 \mathrm{MPa}$ \\
\hline
\end{tabular}


dards. The sampling for testing the compressive strength and for the physico-chemical analysis was carried out with core bores.

Within the project, the strength class of the concrete was defined as $20 \mathrm{MPa}$. The results for the compressive strength determined on the samples and collected within the research are summarized in Table 3.

The mineralogical composition of the concrete was evaluated with an X-ray diffraction analysis, its results are presented in Table 4.

Table 4: Results of the mineralogical analysis of the concrete Tabela 4: Rezultati mineraloške sestave betona

\begin{tabular}{|c|c|}
\hline Sampling point & Identified minerals \\
\hline $\begin{array}{c}\text { Stationing } \\
0.57 \mathrm{~km} \text { - tertiary sediments }\end{array}$ & $\begin{array}{c}\text { Calcite, ettringite, gypsum, } \\
\text { quartz, feldspar }\end{array}$ \\
\hline $\begin{array}{c}\text { Stationing } \\
\text { km }- \text { quaternary } \\
\text { sediments }\end{array}$ & $\begin{array}{c}\text { Calcite, portlandite, calcium } \\
\text { silicate hydrate II, mono- } \\
\text { sulphate, quartz, feldspar }\end{array}$ \\
\hline $\begin{array}{c}\text { Stationing } \\
\text { Calcite, portlandite, }\end{array}$ \\
\hline $.68 \mathrm{~km}$ - tertiary sediments \\
$\begin{array}{c}\text { Stationing } \\
\text { monosulphate, quartz, feldspar }\end{array}$ \\
$\begin{array}{c}\text { Calcite, ettringite, gypsum, } \\
\text { monosulphate, quartz, feldspar }\end{array}$ \\
\hline $\begin{array}{c}\text { Stationing } \\
\text { mertiary sediments }\end{array}$ & $\begin{array}{c}\text { Calcite, portlandite, calcium } \\
\text { silicate hydrate II, mono- } \\
\text { sulphate, quartz, feldspar }\end{array}$ \\
\hline $\begin{array}{c}\text { Stationing } \\
\text { km -quaternary } \\
\text { sediments }\end{array}$ & $\begin{array}{c}\text { Calcite, portlandite, calcium } \\
\text { silicate hydrate II, carbonate } \\
\text { complex, monosulphate, } \\
\text { quartz, feldspar }\end{array}$ \\
\hline
\end{tabular}

It is clear that in certain locations, already after two years of the groundwater penetration, a massive degradation of the concrete occurred. The concrete's compressive strength in the affected areas is only about half of its original value. This finding corresponds completely with the results of the physical and chemical analyses showing massive corrosion formations (gypsum, secondary ettringite) in the microstructure of the affected concrete. In addition, the physical and chemical analyses showed that in some areas the water penetrating the lining caused quite an intense decomposition ("a washout") of the cement matrix. This, of course, resulted in a decrease in the strength of the concrete.

So, massive and negative symptoms occurred after two years of the operation of the collector. On the basis of the experience with similar types of structures, supported by a mathematical simulation, an assumption was formulated, according to which in approximately two years, in some parts of the collector the rate of degradation of the lining will be so high that the static load of the collector will be affected.

Therefore, it was necessary to repair the structure. The first phase of the repair work related to the most affected areas. In these locations, the entire layer of the concrete along the lining was removed and the reinforcement affected by extreme corrosion was replaced. The removed concrete was then replaced with the repair material. Due to the highly aggressive environment, a mate- rial with a matrix based on alkali-activated substances was used.

\section{REPAIR MATERIAL BASED ON ALKALI-ACTIVATED MATERIALS}

When developing a formula based on alkali-activated materials, we used the results from earlier researches. ${ }^{2-7}$

In terms of the properties of the resulting mixture, the compositions of individual components are important. The basic characteristics of the materials used for producing the mixtures with alkali-activated matrices are summarized in the following tables (Tables 5 to 7).

Table 5: Chemical composition of metakaolin

Tabela 5: Kemijska sestava metakaolina

\begin{tabular}{|c|c|}
\hline Component & Representation (\%) \\
\hline $\mathrm{Al}_{2} \mathrm{O}_{3}$ & 41.90 \\
\hline $\mathrm{SiO}_{2}$ & 52.90 \\
\hline $\mathrm{K}_{2} \mathrm{O}$ & 0.77 \\
\hline $\mathrm{Fe}_{2} \mathrm{O}_{3}$ & 1.08 \\
\hline $\mathrm{TiO}_{2}$ & 1.80 \\
\hline $\mathrm{MgO}$ & 0.18 \\
\hline $\mathrm{CaO}$ & 0.13 \\
\hline
\end{tabular}

Table 6: Chemical composition of slag

Tabela 6: Kemijska sestava žlindre

\begin{tabular}{|c|c|}
\hline Component & Representation (\%) \\
\hline $\mathrm{Al}_{2} \mathrm{O}_{3}$ & 7.42 \\
\hline $\mathrm{SiO}_{2}$ & 38.51 \\
\hline $\mathrm{CaO}$ & 36.26 \\
\hline $\mathrm{MgO}$ & 10.11 \\
\hline $\mathrm{K}_{2} \mathrm{O}$ & 0.43 \\
\hline $\mathrm{Fe}_{2} \mathrm{O}_{3}$ & 0.74 \\
\hline $\mathrm{TiO}_{2}$ & 0.026 \\
\hline
\end{tabular}

Table 7: Chemical composition of sodium-silica water glass

Tabela 7: Kemijska sestava vodnega stekla Na-Si

\begin{tabular}{|c|c|}
\hline Component & Representation (\%) \\
\hline $\mathrm{SiO}_{2}$ & 50.82 \\
\hline $\mathrm{Na}_{2} \mathrm{O}$ & 26.25 \\
\hline Water & 22.12 \\
\hline Silicate module & 1.92 \\
\hline
\end{tabular}

Table 8: Formula of the repair mixture based on alkali-activated materials

Tabela 8: Sestava reparaturne mešanice na osnovi z alkalijo aktiviranega materiala

\begin{tabular}{|c|c|}
\hline Ingredient & $\begin{array}{c}\text { Ingredient dosage of concrete, } \\
\mathrm{kg} / \mathrm{m}^{3}\end{array}$ \\
\hline Slag & 430 \\
\hline Sodium-silica glass & 95 \\
\hline Metakaolin & 50 \\
\hline Water & 180 \\
\hline Aggregates & 1750 \\
\hline
\end{tabular}

Aggregates with fractions of $0-4 \mathrm{~mm}$ and $4-8 \mathrm{~mm}$ were used as the filler. The particle-size distribution 
curve was optimized according to the Empa II procedure. $^{5}$

The mixture composition is given in Table $\mathbf{8}$.

This mixture was applied in the locations of the lining, where it was necessary to remove the original concrete. The effectiveness of this measure was then evaluated using the procedure described in the following section.

\section{PERFORMANCE ANALYSIS OF THE NEW MATERIAL}

The efficiency, or durability, of the repair material was evaluated as follows: One year after the repairs, control samples were taken from the localities in which the repair mixture in question was applied. A set of physico-mechanical and physico-chemical parameters of these samples was determined. Attention was focused especially on the following parameters:

- the tensile strength of the surface layers;

- the compressive strength;

- the microstructure, analysed with physico-chemical methods. The X-ray diffraction analysis and the scanning electron microscopy were used.

The tensile-strength test of the surface layers was made "in situ", the sampling for testing the compressive

(a)

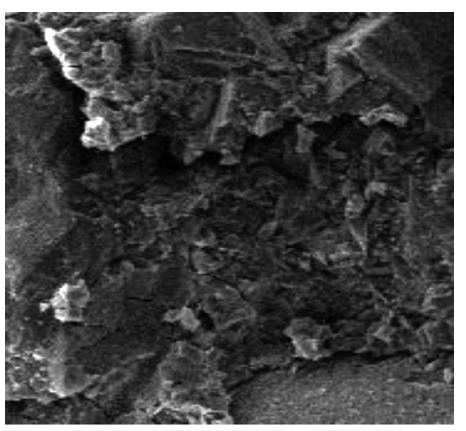

(b)

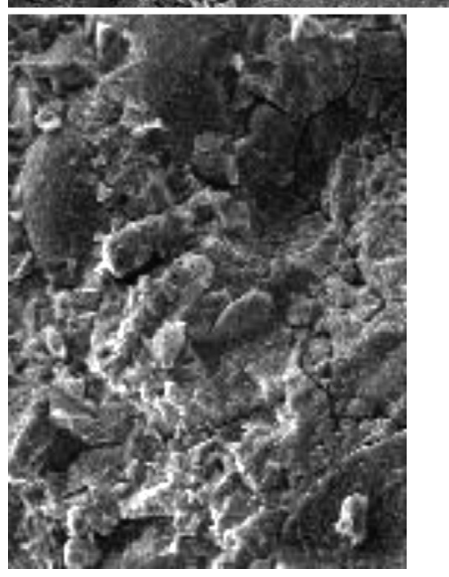

Figure 3: Detailed analysis of the microstructure showed a: a) de-facto amorphous phase of the matrix for both the reference material and $b$ ) the exposed material of the collector

Slika 3: Podrobnejša analiza mikrostrukture pokaže: a) amorfno osnovo tako $\mathrm{v}$ primerjalnem materialu kot tudi $\mathrm{v}$ b) izpostavljenem materialu v kolektorju strength and for the physico-chemical analysis was carried out with core bores.

These analyses were performed with the procedures that are in accordance with the provisions of the relevant technical standards. The samples representing the repair material were then subjected to the same set of experiments after being stored for about $28 \mathrm{~d}$ and $360 \mathrm{~d}$ in standard laboratory conditions (i.e., $t=(20 \pm 2){ }^{\circ} \mathrm{C}, \varphi=$ $(60 \pm 5) \%)$. These values were considered as the references. The comparison of the values recorded on the reference bodies and the samples of the repair materials exposed to the environment of the collector for one year was the essential criterion in the evaluation of the effectiveness of the repairs carried out. The data found with the set of experiments are shown below (Tables 9 and 10).

Table 9: Results of the strength-parameter tests of the repair material Tabela 9: Rezultati preizkusa trdnosti reparaturnega materiala

\begin{tabular}{|c|c|c|c|}
\hline sample identification & $\begin{array}{c}\text { Bulk } \\
\text { density } \\
\left(\mathrm{kg} / \mathrm{m}^{3}\right)\end{array}$ & $\begin{array}{c}\text { Tensile } \\
\text { strength of } \\
\text { surface } \\
\text { layers } \\
(\mathrm{MPa})\end{array}$ & $\begin{array}{c}\text { Compres- } \\
\text { sive } \\
\text { strength } \\
(\mathrm{MPa})\end{array}$ \\
\hline $\begin{array}{c}\text { Reference set - stored for } \\
\text { 28 d in standard } \\
\text { laboratory conditions }\end{array}$ & 2450 & 2.1 & 35.6 \\
\hline $\begin{array}{c}\text { Reference set - stored for } \\
\text { one year in standard } \\
\text { laboratory conditions }\end{array}$ & 2400 & 2.3 & 36.2 \\
\hline $\begin{array}{c}\text { Stationing 0.57 km - } \\
\text { significant sulphate } \\
\text { aggressiveness, annual } \\
\text { exposure }\end{array}$ & 2420 & 1.9 & 34.3 \\
\hline $\begin{array}{c}\text { Stationing 4.42 km - } \\
\text { tertiary sediments, annual } \\
\text { exposure }\end{array}$ & 2380 & 2.0 & 34.0 \\
\hline
\end{tabular}

Table 10: Results for the mineralogical composition of the repair material

Tabela 10: Mineraloška sestava reparaturnega materiala

\begin{tabular}{|c|c|}
\hline Sample identification & Identified minerals \\
\hline $\begin{array}{c}\text { Reference set }- \text { stored for } \\
\text { 28 in standard laboratory } \\
\text { conditions }\end{array}$ & $\begin{array}{c}\text { Calcium silicate hydrate II, } \\
\text { goethit, quartz, feldspar }\end{array}$ \\
\hline $\begin{array}{c}\text { Reference set }- \text { stored for one } \\
\text { year in standard laboratory } \\
\text { conditions }\end{array}$ & $\begin{array}{c}\text { Calcium silicate hydrate II, } \\
\text { goethit, quartz, feldspar }\end{array}$ \\
\hline $\begin{array}{c}\text { Stationing 0.57 km - signi- } \\
\text { ficant sulphate aggressiveness, } \\
\text { annual exposure }\end{array}$ & $\begin{array}{c}\text { Calcium silicate hydrate II, } \\
\text { goethit, quartz, feldspar }\end{array}$ \\
\hline $\begin{array}{c}\text { Stationing 4.42 km - tertiary } \\
\text { sediments, annual exposure }\end{array}$ & $\begin{array}{c}\text { Calcium silicate hydrate II, } \\
\text { goethit, quartz, feldspar }\end{array}$ \\
\hline
\end{tabular}

The microstructure of the material was also analysed using the scanning electron microscopy (Figure 3).

On the basis of the above findings we can say that in terms of both the strength parameters and mineralogy, the parameters of the repair material exposed to the highly corrosive environment are quite comparable with the reference parameters. 


\section{CONCLUSIONS}

The article deals with the way of repairing an underground collector affected, in some areas, by underground waters with a highly aggressive chemical effect. Already in one or two years of the collector's operation these waters caused distinct disorders. In the affected areas there was a significant reduction in the mechanical properties of the concrete, and its ability to protect the reinforcement against the corrosion was significantly reduced. Thus, local repairs were carried out, whereby a material with its matrix based on alkali-activated materials was used as the repair material.

The matrix of the repair material was composed of a mixture of blast-furnace slag and metakaolin. Water glass was used as the activator. The matakaolin added to the mixture was to reduce the negative effects associated with the autogenous shrinkage that usually accompanies the aging of the materials with pure-slag matrices., 3,6

The control tests that were conducted one year after the repair work demonstrated that the aggressive effects of the water did not result in a decrease in the strength of the repair material. Neither were negative changes found in its microstructure. It was also established that the reinforcement was very well protected against the corrosion due to the repair material.

It is clear that the period (one year of application) is short in terms of the durability of the structures, and for a precise verification of our findings, we will need to continue with the monitoring of the concerned construction. However, despite this fact, it can be noted that so far the results have indicated a high potential of the material with a matrix based on alkali-activated materials in the repair of the reinforced concrete structures exposed to chemically aggressive environments.

\section{Acknowledgements}

This research was done with the financial help of project GAČR 14-25504S, Research of Behaviour of Inorganic Matrix Composites Exposed to Extreme Conditions, and EU project The Research and Development for Innovation, reg. number CZ.1.05/2.1.00/03.0097, through the activities of regional centre AdMaS Advanced Materials, Structures and Technologies.

\section{REFERENCES}

${ }^{1}$ R. Drochytka, J. Dohnálek, J. Bydžovský, V. Pumpr, A. Dufka, P. Dohnálek, Technické podmínky pro sanace betonových konstrukcí TP SSBK III., 1. edition, Sdružení pro sanace betonových konstrukcí, (The specifications for the reinstalment of concrete structures TP SSBK III, 1st edition, Association of Concrete Structure Reinstalment), Brno 2013, 262 pages

${ }^{2}$ M. Palacios, F. Puertas, Effect of shrinkage reducing admixtures on properties of alkali-activated slags, mortars and pastes, Cement and Concrete Research, 37 (2007) 5, 691-702, doi:10.1016/j.cemconres. 2006.11.021

${ }^{3}$ P. Rovnaník, Vliv působení vysokých teplot na stavební materiály na bázi alkalicky aktivovaných pojiv, habilitační práce (The influence of high temperatures on building materials based on alkali-activated binders, habilitation thesis), University of Technology in Brno, 2012

${ }^{4}$ W. Brylicki, J. Malolepszy, S. Stryczek, Alkali activated cementitious material for drilling operation, 9th International Congress on the Chemistry of Cement, New Delhi, India, 3 (1992), 312-318

${ }^{5}$ D. Wu, Y. Pei, B. Huang, Slag-mug mixtures improve cementing operations in China, Oil and Gas Journal, (1996), 95-100

${ }^{6} \mathrm{X}$. Chen, N. Yang, Influence of polymeric structure of granulated blast furnace slag on their hydraulic activities, 2nd Beijing International Symposium on Cement and Concrete, Beijing, 1989, 346-351

${ }^{7}$ J. Malolepszy, J. Deja, W. Brylicky, Industrial application of slag alkaline in concretes, 9th international conference on alkaline cements and concretes, Kiev, 2 (1994), 989-1001 